\title{
MOTHERS' EXPERIENCES OF LABOUR IN A TERTIARY CARE HOSPITAL
}

\author{
Dr MS Maputle \\ Ph D \\ Ph D student, Department of Nursing, Faculty of Health Sciences, University of Johannesburg
}

\section{Prof A Nolte}

Ph D

Professor, Department of Nursing, Faculty of Health Sciences, University of Johannesburg

Corresponding author: agwnolte@uj.ac.za

Keywords: experience of labour; accommodative midwifery actions; maximise human and material infrastructure; midwife; South Africa

\begin{abstract}
The purpose of the study was to explore and describe experiences of mothers during childbirth in a tertiary hospital in the Limpopo Province. This was achieved through a qualitative research study which was exploratory, descriptive, contextual and inductive in nature. A sample of 24 mothers participated in this study. Data obtained from unstructured in-depth interviews were analysed according to the protocol by Tesch (1990, cited in Cresswell, 1994:155). Five themes were identified, namely mutual participation and responsibility sharing, dependency and decision-making; information sharing and empowering autonomy and informed choices; open communication and listening; accommodative/non-accommodative midwifery actions; and maximising human and material infrastructure. The themes indicated experiences that foster or promote dependency on midwifery care. Guidelines on how to transform this dependency into a mother-centered care approach during childbirth are provided.
\end{abstract}

\section{OPSOMMING}

Die doel van die studie was om moeders se belewenis van kindergeboorte in 'n tersiêre hospitaal in die Limpopo Provinsie te verken en te beskryf. Dit is gedoen deur middel van kwalitatiewe navorsing wat verkennend, beskrywend, en kontekstueel was. ' $n$ Steekproef van 24 moeders het aan die studie deelgeneem. Inligting is verkry deur middel van ongestruktureerde in-diepte onderhoude. Hierdie inligting is geanaliseer aan die hand van Tesch (1990: aangehaal in Creswell, 1994:155) se protokol. Die volgende kategorieë is geïdentifiseer, wedersydse deelname en gedeelde verantwoordelikhede, afhanklikheid en besluitneming, deel van inligting, bemagtiging tot outonomie en ingeligte keuse, oop kommunikasie en luister, akkommoderende/nie-akkommoderende vroedvrou-aksies en bevordering van menslike en materiële infrastrukture. Die resultate van die onderhoude het belewenisse blootgelê wat dui op die bevordering van afhanklikheid in vroedvrouversorging. Riglyne om hierdie afhanklikheid te verander in ' $n$ moedergesentreerde benadering word verskaf. 


\section{INTRODUCTION}

The Limpopo Province consists of six districts, namely; Capricorn, Mopani, Bohlabela, Vhembe, Sekhukhune and Waterberg. Each is further divided into sub-districts and municipalities. As indicated in the Department of Health Reports (2002:52), the total population in the province is 5.514 million of which $54 \%$ were females. Of the total female population, $45 \%$ were in the childbearing age group. The health service structure consisted of one (1) tertiary institution, six (6) districts hospitals (level 2) and thirty-six (36) community hospitals (level 1 ). The tertiary hospital is a referral hospital for levels 1 and 2 hospitals within the Province. In the Limpopo Province more mothers currently give birth in hospitals than at home. According to the Department of Health Report (2002:52), the Province had a total of 43 hospitals, of which 40 had functioning maternity units for deliveries and an estimated $64 \%$ of births occurred in the hospitals.

When mothers enter the hospital to give birth they are usually unfamiliar with both the surroundings and the structure of the ward and they are not well acquainted with the rules that govern behaviour in the obstetric unit setting. The policies and procedures are strategically placed in the ward and midwives seem to regard it as their responsibility to ensure that the rules are adhered to. Such standardised routines do have some merit, but when followed without skilled assessment they may pose the risk of depersonalising the mothers and discouraging any participation and involvement during midwifery care (Pearson, Vaughan \& Fitzgerald, 1998:34). The care becomes midwife-centered and not patient-centered. It might become more important for the midwives to meet their own needs and solve their own problems instead of that of the woman in labour.

The pressure from society and increased understanding of human rights through the Patients' Charter and BathoPele Principles have highlighted the restrictive nature of the biomedical model, the alternative approach being the provision of woman-centered care. The Batho-Pele Principles seek to introduce a customer-focused approach that aims at putting pressure on systems, procedures, attitudes and behaviour within the childbirth units and re-orienting the attending midwives in the customers' favour, an approach which puts people first (Department of Public Service and Administration, 1997).
It was further indicated that this does not necessarily mean introducing more rules and centralised processes, or micro-managing service delivery activities. Rather, it involves creating a framework for delivery of public services which treats citizens more like customers and enables them to hold public servants to account for the services they render.

The White Paper on Transforming Service Delivery (Department of Public Service and Administration: 1997) through the eight Batho-Pele Principles (consultation, service standard, courtesy, access, information, openness and transparency, redress and value for money) aim at improving the entire standard of the public service and effective service delivery. Services should be based on a customer-orientated framework.

Sandall (1995:201) is in support of customer-oriented service delivery when he points out that the philosophy and focus should shift from technologisation to personalisation, and to creation of the paradigm of a woman-centered practice based on equal partnership between mothers and attending midwives.

\section{PROBLEM STATEMENT}

The challenges posed by the utilisation of the biomedical model are that attending midwives tend to continue to view mothers as physical beings and pay little attention to the broader characteristics of human nature. Mothers seem to have limited powers compared to their attending midwives who focus mainly on completing certain tasks before handing over the report to the next midwife on duty. Thus little effort is expended on meeting the needs of mothers as individuals.

Once mothers seek midwifery care during childbirth, they are expected to follow set standards and midwifery protocols, because the midwives follow set standards of procedures to monitor and regulate physiological developments. While these policies and procedures might make sense from the standpoint of midwifery care and possibly also reflect the priorities dictated by the biomedical model, they do not always manifest the experiences, needs and priorities of mothers during childbirth. It is therefore important to determine how mothers experience the care that they receive during 
childbirth.

\section{PURPOSE OF THE STUDY}

The aim of this study was to explore and describe experiences of mothers during childbirth in a tertiary hospital in the Limpopo Province. This would be done as a first step towards eventually developing a mothercentered childbirth model that would be utilised to assist the attending midwives in the facilitation of mutual participation when managing mothers during childbirth (The model will not be discussed in this article).

\section{DEFINITIONS OF TERMS}

Concepts used in this study are defined as follows:

\section{Experience}

Experience is an event or circumstances undergone or lived through (Oxford English Dictionary, 1999). It is directly related to a person's internalisation of an event, which he/she has personally lived through. In this study experiences include emotions, thoughts, preferences, perceptions and values.

\section{Childbirth}

In this study childbirth refers to the process when a mother gives birth to a child, and includes the first, second and third stages of labour. It includes all vaginal births.

\section{Biomedical Model}

Biomedical model refers to the model on which nurses base their practice and view patients as biological beings and pay little attention to the wider characteristics of human nature (Pearson, Vaughan \& Fitzgerald, 1998:27). It refers in this study to the midwife taking full responsibility for controlling the childbirth process without the mother participating and sharing responsibility.

\section{RESEARCH METHODOLOGY}

Research design and methods of data
collection
A qualitative design was chosen for this project, as the focus was on exploring and describing the experiences of childbirth by mothers. The research thus aims to provide a description and an exploration of a particular phenomenon or experience, within the context of the phenomenon's specific setting and world significance by using a phenomenological research method.

\section{Population and sampling}

The population consisted of all mothers who had been admitted to deliver their babies in the obstetric unit of a tertiary hospital in the Capricorn district, Limpopo Province. Non-probability, convenience sampling was used in the study.

Mothers were selected from the obstetric unit of one hospital in the Capricorn district in the Limpopo Province. This hospital was used as it is an obstetrical referral hospital for all six districts in the Limpopo Province. The researcher selected available mothers in the first stage of labour who meet the inclusion criteria. The mothers who were selected were interviewed in the post-natal ward within 24 hours after delivery. The interviews were held in the post-natal ward to enable mothers to describe their experiences of all three stages of labour.

The criteria for inclusion were mothers:

- with a term pregnancy;

- in early active labour, who went through the first, second and third stages of labour in the hospital;

- with the presence of a fetal heart rate; and

- that should have been able to understand and speak English.

In this research the adequacy of the sample was attained when sufficient data had been collected so that saturation occurs and variation is both accounted for and understood. According to Glaser and Strauss (in Strauss and Corbin, 1990:188) saturation means that no new or relevant data seem to emerge regarding a category, the category development is dense and the relationship between the categories are well established. Twenty-four mothers were sampled when saturation was achieved.

\section{Data collection}


Permission to gain entry into childbirth units was obtained following approval from the Ethics Committee of the Rand Afrikaans University, the Provincial Department of Health, and the hospital concerned. The project was explained to the unit managers, attending midwives and mothers of the obstetrical and postnatal wards. Written informed consent was obtained from mothers.

Unstructured in-depth interviews were conducted in English with the mothers. The question directed at the mothers was: "Could you please tell me about your experiences of childbirth in this hospital?"

The researcher contacted each participant in the postnatal ward to confirm an appointment for the interview at a quite place in the post-natal ward and at an appropriate time for the participants. The interviews were tape-recorded and comments were made about sensitive ethical issues such as maintaining confidentiality of data and preserving the anonymity of the informants and using research for its intended purposes (Creswell, 1994:148). The tapes were numbered and the participants' names were nowhere mentioned. The ethical standards as set by DENOSA (Democratic Nursing Organisation of South Africa) were adhered to before and during the interview (DENOSA, 1998:1-7).

The researcher created a context that was conducive to mutual trust between researcher and participant. Other ethical issues that were considered were the following: Privacy was ensured during the interview. The participants were ensured that their participation is entirely voluntarily and that they could withdraw from the research at any stage if they feel so. The interviews would be stopped if the participant suffered severe stress during the interview. The possibility of referring the patients for counselling was discussed with the patients after the interview. During the interview communication skills for example probing was used to obtain the necessary information.

A pilot study was conducted with one mother to refine the question. The question was asked to one mother and the interview was conducted as planned. The reason was to see whether the question was clear to the mother and whether the interview developed as planned. The mother understood the question and the interview went well, so no changes were made to the question and interview procedure. This patient and interview were therefore added to the main sample.

\section{Data analysis}

Tape recordings of the interviews were transcribed verbatim in the language in which the interviews were held. The narrative data from unstructured in-depth interviews were analysed qualitatively through the open coding method (Tesch, 1990, cited in Creswell, 1994:155). Data analysis is a process of bringing order to the data and organising what is collected into concepts, categories and basic descriptive statements (Patton 1987:144).

Another person was requested to also analyse the data according to Tesch's method (Tesch, 1990, in Creswell, 1994:155), independently from the researcher. The two analyses were then compared to ensure trustworthiness. The other analyser was selected as she had experience in qualitative research methodology.

\section{TRUSTWORTHINESS}

The four criteria of trustworthiness, namely, credibility, dependability, transferability and applicability, as outlined in Lincoln and Guba (1985:301-318) were used to establish the trustworthiness of this study.

To enhance credibility the researcher:

- had prolonged contact with the study field. She was a midwife, who had knowledge and clinical experience in this area. The literature that was consulted enabled her further to satisfy the criterion of being knowledgeable about the phenomenon under investigation;

- bracketed existing knowledge and preconceived ideas and especially personal views about the existing problems in the clinical area; and

- conducted the unstructured interviews until data saturation occurred, namely until the collected data were repeated and confirmation of previously collected data took place.

The categories identified by the researcher were compared with those identified by the other coder. No major discrepancies were identified between these persons' analysis of the data. An in-depth literature 
review further confirmed these categories. This enhanced confirmability.

Transferability was ensured by the researcher providing in-depth discussions of the data obtained, data analysis and interpretation of the research findings in a research report.

\section{ETHICAL CONSIDERATIONS}

Ethical considerations were based on the DENOSA Ethical Standards for Nurse Researchers (1998:2.3.22.3.4). The different ethical issues were referred to under data gathering.

\section{FINDINGS AND DISCUSSIONS}

The results from the experiences of the mothers during childbirth revealed five (5) themes, with their subcategories. The themes are not given names, but are referred to as theme 1 , for example. The categories under the themes were then given descriptive names. See Table 1:

\section{Theme 1: Mutual participation, responsibility sharing, dependency and decision-making}

The transcripts of the mothers indicated that there was limited participation and collaboration between them and the midwives during childbirth. The mothers were of the opinion that the midwives did not involve them when providing midwifery care as they just instructed them on what to do and also pointed out that the midwives were not friendly. The following quotes from the mothers' interviews support this feeling: "I was not involved and not informed about my progress, the midwives will examine me and I will only overhear them giving each other the report, but not telling me so that
I can participate." "They know what to do and how to care for us during labour but at times I just felt I'm not involved because l'm just told what to do without being asked. I don't want to be restricted".

According to Berg, Lundgren, Hermansson, and Wattberg (1996:15) mothers are said to have had negative experiences when they lose control of the situation and are not able to participate in the decisionmaking. They further indicate that this occur in situations where midwives take control without giving the mother the necessary time to be involved. Lundgren and Dahlberg (2002:158) point out that it is important for midwives to collaborate by inviting the mothers to participate and be responsible for their care during childbirth.

Some of the mothers, on the other hand, were comfortable with their dependency on the midwives as they indicated that midwives are trained practitioners and they know best. The mothers mentioned that they did not have anything to say, but to listen to the midwives. The following quotes were cited by mothers: "During childbirth I was following all the instructions as was instructed by the sister because the sister has knowledge and I'm ill". "No, during childbirth I don't have anything to say, but I must listen to all what midwives says".

Since the mothers depended on the midwives, it was evident that they had limited decision-making capability. One mother participant indicated that she was willing to take part in the decision-making, but lacked factual or accurate information with regard to the available options, as the following quote indicates: "I would be very happy to be involved in decision-making during childbirth, but this was not the case and we need to be given more information on all issues relating to childbirth because if we are having information we can decide

Table 1: Themes and sub-categories

\begin{tabular}{|c|c|c|c|c|c|}
\hline THEMES & 1. & 2. & 3. & 4. & 5. \\
\hline $\begin{array}{l}\text { SUB- } \\
\text { CATE } \\
\text { GORIES }\end{array}$ & $\begin{array}{l}\text { Mutual participation } \\
\text { and responsibility } \\
\text { sharing, } \\
\text { dependency and } \\
\text { decision-making }\end{array}$ & $\begin{array}{l}\text { Information sharing } \\
\text { and empowering } \\
\text { autonomy and } \\
\text { informed choices }\end{array}$ & $\begin{array}{l}\text { Open } \\
\text { communication and } \\
\text { listening }\end{array}$ & $\begin{array}{l}\text { Accommodative/No } \\
\text { n-accommodative } \\
\text { midwifery actions }\end{array}$ & $\begin{array}{l}\text { Maximize human } \\
\text { and material } \\
\text { infrastructure }\end{array}$ \\
\hline
\end{tabular}


and make informed choices".

Bluff and Holloway (1994:160) point out that women place themselves in the hands of midwives and allow midwives to make decisions for them even if their own wishes are neglected. Nolan (1997:1201) further indicates that midwives are challenged to enforce equal opportunities of making information available and to encourage mothers to take responsibility for their own care. Gibbins and Thomson (2001:310) indicate that being included in and making decisions are reported as being crucial in helping mothers feel in control during childbirth.

\section{Theme 2: Information sharing, empowering, autonomy and informed choices}

When information is shared with regard to childbirth issues and available childbirth options outlined, mothers would be empowered. The mothers emphasised that they were lacking factual information on childbirth issues and on available birth options or choices. They also did not have a good understanding of the available options which they could exercise as the right to choose during childbirth. The following excerpt from some of the mothers' interviews was cited with regard to available options and childbirth issues: "(Laughing ...) I don't know what to expect and what is going to happen during childbirth, the midwives and doctors know exactly, they are able even to determine the complications early and to prevent them".

A lack of shared information was thus seen as an obvious concern. Halliday and Hogart-Scott (2000:63) as well as Gibbins and Thomson (2001:302) state that there are many expressions of the need for information, reassurance and confidence building. They further point out that information given during childbirth enables the mother to take decisions and empowers her to make informed choices. In addition, Richter, Greaney, McKeown, Cornell, Littleton and Pulley. (2001:174) point out that if women are not given adequate information, they may not be able to collaborate with their physicians or be willing or able to ask questions.

\section{Theme 3: Open communication and listening}

From the interview transcripts of mothers, language barriers were cited as a factor that interfered with their interaction during childbirth (especially to mothers who were transferred from other hospitals and who used different languages from that of the attending midwife) because the tertiary hospital provides midwifery care to all racial groups. Some of the mother participants revealed that midwives were impatient, did not listen to them and seldom verified why they had specific preferences. The mother participants felt that the attending midwives lacked listening skills which hindered verbal communication during childbirth as the following remarks made by the interviewees revealed: "Some midwives must be patient and at least listen to what I want to say, they have knowledge and I know that they are busy but even if you ask a small thing they won't listen. For example, if you indicate the preference they don't allow or even listen to why you make such a preference" and "Hmm ... I didn't clearly understand the language of the midwife, but I would like to be assisted especially if there are complications".

\section{Theme 4: Accommodative midwifery actions}

Nolan (1997:1201) suggests that women need to be given information and the opportunity to discuss how that information relates to their particular circumstances before the stresses of labour make it unrealistic to enter into detailed considerations of the pros and cons of childbirth. Contrary to this, the mothers indicated to the midwives that they wanted to be respected and treated as adults. "I expected good care from the midwives. They must treat me as a person, listen to me and empathize with me as I was feeling pain" and "During childbirth there should be communication between the midwife and myself, they must listen and clearly explain to me if what I prefer is not possible".

The mothers indicated that they would prefer the presence of a companion, but were not informed that this was possible as the following expression indicate: "If I knew that my partner could be allowed in, I would have loved that so that he can witness how the baby is delivered and I think this will strengthen the bond between the two of us" and "My partner should be present, he must see how pain is, and he must be involved and understand how painful childbirth is ... 
and he will agree if I opt for sterilisation".

Several authors have spelt out clearly the advantages of the presence of a companion during childbirth (Micklethwait, Beard \& Shaw, 1978:190; Somers-Smith, 1999:105). However, Nolan (1997:1198) points out that in most parts of the world childbirth is a female issue and in the vast majority of traditional cultures it is unheard of for men to be present at birth.

\section{Theme 5: Maximise human and material infrastructure}

A shortage of staff was cited in the interview transcripts. It was pointed out that one midwife would be caring for more than two mothers at the same time. Midwives were not able to spend quality time with the mothers and to verify their preferences. Pelkonen, Perala and Vehvilainen-Julknnen (1998:22) state that a busy and routinised atmosphere has been found to inhibit participation, whereas a friendly, peaceful and secure situation provides opportunities for participation. Staff shortages do contribute to a feeling of tension in clinics and on the wards (Micklethwait et al. 1978:190).

Almost all the mothers agreed that they valued the presence of a midwife who gave detailed information on what to expect and about the progress of the labour. Tarkka, Paunonen and Laippala (2000:188) support this by stating that for the attending midwives to influence the mothers' positive childbirth experiences; they should display empathy, friendliness, tenderness, calmness, alertness, peacefulness and professional expertise.

\section{CONCLUSION}

The results of the interviews seemed to have revealed midwife-centered care rather than mother-centered care during childbirth in the unit of the tertiary hospital in the Capricorn district of the Limpopo Province. In midwifecentered care, it is the midwife who tells mothers what to do and how to behave. This approach during childbirth is characterised by:

- Limited mutual participation and responsibility sharing, which comprise of inadequate participation, limited decision-making scope and a proliferation of practices that foster dependency, and a prevailing authoritative approach within the childbirth unit. The strict routines that are laid down by the regulations seem to depersonalise the mother, resulting in her non-participation. Midwives impose their authority and responsibility to ensure that the rules are adhered to. Mothers are merely seen as the ones who should comply with the rules of the unit while having no power of decision, and there is an over-reliance on technology.

- Limited information sharing and empowering is displayed in this approach, that is, information regarding childbirth issues and awareness of available options are not shared with the mothers which result in powerlessness and a lack of autonomy in childbirth care, this therefore also limits their ability to take independent decisions.

- Hindered/ineffective communication, for example, inadequate listening skills of attending midwives and the existence of a language barrier between mothers and midwives often result in limited participation by the mothers. The midwife-centered care approach seems to limit itself to the physiological processes and the psychosocial aspects of the mother are thus ignored.

- Non-accommodative midwifery actions with regard to poorly defined perceptions of conflicting expectations and unrealistic choices of the mother were manifested. In midwife-centered care, the management of childbirth is focused on the detection of complications, which does not always respect the experience and expectations of childbirth and its outcome.

\section{LIMITATIONS OF THE STUDY}

There are no limitations of the study except possible bias of the persons who did the analysis and interpretations of the data.

\section{RECOMMENDATIONS}

The recommendation is thus to create a model of mother-centered care that is based on equal partnership between the mothers and attending midwives. The procedures to obtain the mother-centered care should be described in detail in this model.

The mother-centered care approach during childbirth, described in this model should be characterised by:

- Participation that requires a mutual, egalitarian and respectful relationship. Equality includes the 
principle of sharing power and responsibility. There should be leverage for negotiation between the mother and the midwife.

- Sufficient information provided by the attending midwives and which is a prerequisite for decisionmaking.

- Interaction between the mother and the midwife should enhance the self-esteem and selfdetermination of the mother. The midwife and the mother should listen to each other because they engage in a dialogue to identify preferences and expectations so that a new strategy for change is constructed.

- In this study the new strategy for change will be to develop a woman-centered childbirth model and to formulate criteria that would be integrated within the Batho-Pele Principles aimed at enhancing the facilitation of mutual participation during childbirth.

\section{REFERENCES}

BERG, M; LUNDGREN, I; HERMANSSON, E \&WAHLBERG, V 1996: Women's experiences of the encounter with the midwife during childbirth. Midwifery, 12(1):11-15.

BLUFF, R \& HOLLOWAY, I 1994: They know best: Women's perceptions of midwifery care during labour and childbirth, Midwifery, 10(3):157-164.

CRESSWELL, JW 1994: Research design: Qualitative and quantitative approaches. Thousand Oaks: Sage.

DEMOCRATIC NURSES ORGANISATION OF SOUTH AFRICA (DENOSA) 1998: Ethical standards for the nurse researcher. Pretoria: DENOSA.

DEPARTMENT OF HEALTH 2002: Saving babies: Third perinatal care survey of South Africa. Pretoria: Government Printers.

DEPARTMENT OF PUBLIC SERVICES ANDADMINISTRATION 1997 : People first: White Paper on Transforming Public Service Delivery. Pretoria: Government Printers.

GIBBINS J \& THOMSON AM 2001: Women's expectations and experiences of childbirth. Midwifery, 17(4):302-313.

HALLIDAY, SV \& HOGARTH-SCOTT, S 2000: New customer to be managed: Pregnant women's views as customers of health care. Journal of Applied Management Studies, 9(1):55-68.

LINCOLN, M \& GUBA, EG 1985: Criteria for assessing trustworthiness of naturalistic inquiry. Thousand Oaks: Sage.

LUNDGREN, I \& DAHLBERG, K 2002: Midwives' experience of the encounter with women and their pain during childbirth. Midwifery, 18(2):155-164.

MICKLETHWAIT, L; BEARD, R \& SHAW, K 1978: Expectations of the pregnant woman in relation to her treatment. British Medical
Journal, 2:188-191.

NOLAN, ML 1997: Antenatal education - Where next? Journal of Advanced Nursing, 25(6):1198-1204.

OXFORD ENGLISH DICTIONARY 1999: University Press.

PATTON, F 1987: Qualitative evaluation and research methods. Newbury Park: Sage.

PEARSON, A; VAUGHAN, B \& FITZGERALD, M 1998: Nursing models for practice. Melbourne, Johannesburg: ButterworthHeinemann.

PELKONEN, M; PERALA, ML \& VEHVILAINEN-JULKNNEN, K 1998: Participation of expectant mothers in decision-making in maternity care: results of a population-based survey. Journal of Advanced Nursing, 28(1):21-29.

RICHTER, DL; GREANEY, ML; McKEOWN, RE; CORNELL, CE; LITTLETON, MA\& PULLEY, L 2001: Developing a video intervention to model effective patient-physician communication and healthrelated decision-making skills for a multi-ethnic audience. JAMWA, 56(4):174-176.

SANDALL, J 1995: Choice, continuity and control: Changing midwifery towards a social perspective. Midwifery, 11(4):201209.

SOMERS-SMITH, MJ 1999: A place for the partner? Expectations and experiences of support during childbirth. Midwifery, 15(2):101-108.

SOUTH AFRICA: DEPARTMENT OF PUBLIC SERVICE AND ADMINISTRATION 1997: People First: White paper on Transforming Public Service delivery. Pretoria: Government Printers.

STRAUSS, A \& CORBIN, J 1990: Basics of qualitative research: Grounded theory procedures and techniques. Newbury Park: Sage.

TARKKA, MT; PAINONEN, M \& LAIPPALA, P 2000: Importance of the midwife in the first time mother's experience of childbirth. Scandanavian Journal Caring Science, 14(3):184-190. 